\title{
Overcoming Obstacles to Evolution Education: In the Beginning
}

\author{
Glenn Branch • Eugenie C. Scott
}

Published online: 20 November 2007

(C) Springer Science + Business Media, LLC 2007

\begin{abstract}
Science teachers are on the front lines of the evolution wars, not only in prominent court cases but also in everyday classroom situations. Owing both to religious opposition to and common misconceptions about evolution, science teachers are in need of support and sometimes guidance. Staff from the National Center for Science Education are looking forward to contributing a regular column, "Overcoming obstacles to evolution education," to Evolution: Education and Outreach, which will discuss a variety of obstacles to effective evolution education and suggest ways of overcoming them.
\end{abstract}

Keywords Creationism - Evolution - Evolution education · Misconceptions · National Center for Science Education . Intelligent design

"Creationists", as the paleontologist Niles Eldredge observes (Eldredge 2005), "have tried repeatedly for well over a hundred years to have evolution either watered down, or preferably completely removed, from the curriculum of America's public schools. Creationists persistently and consistently threaten the integrity of science teaching in America - and this, of course, is of grave concern." To nobody is it a graver concern than the nation's science teachers. From Susan Epperson, who fought against a Scopesera Arkansas law banning the teaching of evolution, to Don Aguillard, who challenged a Louisiana law requiring the teaching of "creation science" along with evolution, to the eight teachers in Dover, Pennsylvania who refused to read a disclaimer that described evolution as "theory, not fact" and endorsed "intelligent design" as a scientifically credible

G. Branch $(\bowtie) \cdot$ E. C. Scott

National Center for Science Education,

P.O. Box 9477, Berkeley, CA 94709-0477, USA

e-mail: branch@ncseweb.org alternative, science teachers have been, willingly or not, at the front lines in America's ongoing wars over evolution education.

It is not only in the courts (Larson 2003) that science teachers are embattled. A story in The New York Times about a Georgia teacher who resisted pressure to downplay her presentation of evolution in her classes, despite the fact that it pervades the assigned textbook and is mandated by the state science standards, noted that despite the occasional battle that dominates the headlines, "More commonly, the battling goes on locally, behind closed doors, handled so discreetly that even a teacher working a few classrooms away might not know" (Winrap 2006). Indeed, in an informal survey conducted in March 2005 among members of the National Science Teachers Association, no fewer than $31 \%$ of the respondents indicated that they felt pressure to include nonscientific alternatives to evolution such as "creation science" or "intelligent design" in their science classroom, whereas $30 \%$ indicated that they experienced pressure to omit or downplay evolution and related topics in their science curriculum (National Science Teachers Association 2005).

Such pressure is often bolstered by the prevalence of misinformation about evolution and the nature of science. Creationists constantly complain that the evidence for evolution is overstated, unreliable, or even fraudulent, and they obsessively rummage through the scientific literature for passages to quote out of context to show that evolution is - in a commonly used phrase - a theory in crisis. Such passages can then be brandished to teachers, who, faced with a recitation of creationist propaganda about, for example, the alleged faultiness of the evidence for adaptive crypsis in Biston betularia (the peppered moth of textbook fame), may not know where to go to learn that the peppered moth remains a fine example of natural selection in action 
(Mallet 2004). Less subtle but similarly hard to counter is the strategy recommended by Ken Ham, the president of the creationist ministry Answers in Genesis, who likes to train schoolchildren to respond to anyone making a statement about the prehistoric past by impertinently piping, "Were you there?"

It is tempting to ignore creationists as obvious cranks, like believers in UFOs, the Loch Ness monster, and fairies. But they reflect popular opinion, even as they seek also to influence it. According to a 2005 survey, $40 \%$ of Americans agreed with, $39 \%$ disagreed with, and $21 \%$ were unsure about the proposition "Human beings, as we know them, developed from earlier species of animals". The United States is almost unique in the developed world for its rate of doubt about evolution with only Turkey faring worse. The situation is not clearly improving either. The authors of a longitudinal review of scientific literacy around the world report, "After 20 years of public debate, the percentage of U.S. adults accepting the idea of evolution has declined from $45 \%$ to $40 \%$ and the percentage of adults overtly rejecting evolution declined from $48 \%$ to $39 \%$. The percentage of adults who were not sure about evolution increased from $7 \%$ in 1985 to $21 \%$ in 2005 " (Miller et al. 2006).

Moreover, it is not as though evolution is intrinsically easy to teach in the first place, even in the absence of pressure from those who object to it on religious grounds. Teachers are all too aware, and researchers in cognitive psychology (Lombrozo et al. 2006) and science education confirm (Alters and Alters 2001), that resistance to evolutionary concepts begins in childhood. Students bring to the classroom a host of predictable misconceptions about evolution: that fitness is a matter of strength, rather than reproductive success; that it is individuals, rather than populations, that evolve; that evolution is linear and progressive, rather than opportunistic and branching, and so on. Although there is encouraging progress on a number of fronts, including concerted outreach efforts from a number of scientific organizations and educational groups alike, it remains distressingly true that both pre-service and in-service teachers are not getting the guidance or scientific information they need to teach evolution effectively in a climate of ignorance of, skepticism about, and hostility toward evolution.

We at the National Center for Science Education are therefore pleased to be involved with Evolution: Education and Outreach in its efforts to promote accurate understanding and comprehensive teaching of evolution to a wide audience, including, and especially including, science teachers. As the only national organization that specializes in defending the teaching of evolution in the public schools, NCSE's primary goal is to assist teachers, as well as parents, scientists, and concerned citizens in general, who are confronting threats to evolution education in their local communities and in their states. We blush to say it, but
Niles Eldredge dedicated his book The Triumph of Evolution: and the Failure of Creationism "to the inspired and unflagging efforts of Eugenie Scott and her entire staff at the National Center for Science Education-frontline defenders of quality science education in America" (Eldredge 2000).

NCSE is particularly delighted to be contributing a regular column-"Overcoming obstacles to evolution education"- to Evolution: Education and Outreach as part of those efforts. For the benefit of teachers who face challenges from students and parents, some of our columns will debunk specific instances of creationist misinformation about science-from the antediluvian canard about the incompatibility of evolution with the second law of thermodynamics to whatever the latest creationist distortion of evo-devo (evolutionary developmental biology) turns out to be-and recommending resources for teachers to become able to evaluate such claims on their own. And because it is useful for teachers to understand the motivations and presuppositions behind such challenges, we will also be discussing the history of creationism, its roots in the inerrantist tradition of biblical fundamentalism, and the panoply of its present-day forms, from "intelligent design" to "creation science" and even to geocentrism - still alive and well, 464 years after Copernicus (Redmon 2007).

But that is not all. In addition to creationist challenges from students, parents, and even-unfortunately-colleagues, teachers are at risk of encountering organized opposition to evolution education, often from the local school board. That was what happened in Dover, Pennsylvania and in Cobb County, Georgia where the school board ordered labels describing evolution as "a theory, not a fact" to be affixed to biology textbooks, to cite only two prominent cases within the last few years. Accordingly, we will discuss what is wrong with such policies - explaining, for example, the creationist underpinnings of the "theory, not fact" mantra, the speciousness of the notion that it is only fair to teach creationism alongside evolution, and the way in which slogans such as "teach the controversy" and "critical analysis" invariably conceal a creationist agenda (Scott and Branch 2003) - and offer suggestions for ways in which teachers can resist antievolution bullying when such problems arise.

Furthermore, as the title "Overcoming obstacles to evolution education" suggests, our intention is not to confine the column just to the creationism/evolution controversy, NCSE's primary area of expertise, but to address a wide variety of the obstacles teachers encounter when they teach evolution. So we will also be discussing the common misconceptions about evolution and offering suggestions about how teachers ought to address them to teach evolution effectively. Such obstacles include not only scientific misconceptions, such as thinking of evolution as a 
great chain of being instead of as a tree of life, but also historical, religious, and philosophical misconceptions: the sadly common beliefs that evolutionary theory was devised as part of a sinister atheist plot, that evolution entails the meaninglessness of life, or that a theory in science is a mere speculation or conjecture, for example, are all obstacles to effective evolution education at least as pernicious as the most carefully wrought creationist argument.

And we may take the column even further-assessing new and old approaches to improving the effectiveness of evolution education, pondering the way in which folk concepts (such as purpose, design, and chance) present challenges to students taking biology classes, and even presenting inspiring or cautionary profiles of individuals or episodes important to evolution education. Most of all, though, what we want to accomplish with the "Overcoming obstacles to evolution education" column is to address the questions that you, the readers of this magnificent experiment in connecting teachers with scientists for the benefit of evolution education, regard as pressing. We want to hear from you, so that all of us-NCSE; the contributors to and the editors and editorial board of Evolution: Education and Outreach; you, its readers; and everybody concerned with the integrity of science education - can work together to defend the teaching of evolution in the public schools.

\section{References}

Alters B, Alters S. Defending evolution in the classroom: a guide to the creation/evolution controversy. Sudbury, MA: Jones and Bartlett; 2001.

Eldredge N. The triumph of evolution: and the failure of creationism. New York: Freeman; 2000.

Eldredge N. The unmetabolized Darwin. In: Scott EC (2005) Evolution vs. creationism: an introduction. Berkeley: University of California Press; 2005. p. ix-xii.

Larson E. Trial and error: the American controversy over creation and evolution. 3rd ed. New York: Oxford University Press; 2003.

Lombrozo T, Shtulman A, Weisberg M. The intelligent design controversy: lessons from psychology and education. Trends Cogn Sci 2006;10(2):56-7.

Mallet J. The peppered moth: a black and white story after all. Genetics Society News 2004;50:34-8.

Miller JD, Scott EC, Okamoto S. Public acceptance of evolution. Science 2006;313(5788):765-6.

National Science Teachers Association. (2005) Survey indicates science teachers feel pressure to teach nonscientific alternatives to evolution (press release). http://www.nsta.org/about/pressroom. aspx?id $=50377$.

Redmon J. Evolution memo prompts call for apology. The Atlanta Journal-Constitution 16 February, 1D; 2007.

Scott EC, Branch G. Evolution: what's wrong with "teaching the controversy". Trends Ecol Evol 2003;18(10):499-502.

Winrap M. Evolution's lonely battle in a Georgia classroom. The New York Times 28 June, B9; 2006. 